\title{
Ajaran-Ajaran Syiah: Refleksi Dari Masyarakat Aceh
}

\author{
Abidin Nurdin, Al Chaidar, Muhammad bin Abubakar \\ Universitas Malikussaleh, Aceh, Indonesia
}

\section{Abstract}

In the Shiite (Syiah) concept, human leadership is rooted in Divine leadership. Allah chose man as the caliph on earth. For human salvation, He chose men who already have perfection in the nature and development of their personality. These humans are the Prophets who become priests in religious matters, and leaders in social affairs. The Prophets were followed by the Aushiya (testament recipients). From the aushiya continued by the fakih. Human leadership is thus the existence of God's leadership over humans. At this point, the Shiites believe in a unity of leadership, namely worldly leadership (social government) and spiritual leadership (spiritual religion). But what's interesting is that selection to become a fakih is very difficult and extra tight. Therefore, it is not difficult to find among the Shiites a bureaucratic elite leader who is proficient and has deep knowledge of his religion in a person at once

\section{Keywords}

Shiite, Syiah; Islam Aceh; kepemimipinan

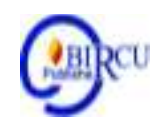

\section{Pendahuluan}

Perlu dicatat bahwa mazhab Syiah menjadi polemik di dunia Islam, juga di Indonesai sehingga Jalaluddin pernah menjadi sorotan dari Majelis Ulama Indonesia Jawa Barat juga berbagai kalangan dengan berdirinya Yayasan Muthahhari. Padahal menurutnya Muthahhari tidak mempelajari secara khusus mazhab Syi'ah, di pesantren ini dipelajari semua mazhab fikih (Abu Hanifa, Malik, Syafi'i dan Hanbali) juga pemikiran-pemikiran lainnya. Meskipun tidak sedikit yang menampakkan warna simpati terhadap pemikiran Syi’ah.

Menarik untuk dicatat pandangan M. Amien Rais, Nurcholish Madjid dan Abdurrahman Wahid memandang Syi'ah lebih obyektif dan proporsional atau lebih tepat pada wacana pemikiran atau school of thouhgt. Amien Rais dalam pengantar buku Ali Syariati seorang sosiolog Islam Syi'ah lulusan Barat. Amien Rais menulis;

Dr. Ali Syari'ati adalah seorang Syi'i. Sedangkan penerjemahnya adalah seorang Muslim Sunni. Dorongan untuk menerjemahkan buku ini bukanlah untuk menawarkan percikan-percikan pemikiran Syi'ah di Indonesia. Bagi penerjemah, perbedaan Syi'ahSunnah adalah warisan historis kuno yang telah menyebabkan lemahnya umat Islam sebagai satu keseluruhan. Yang perlu kita kerjakan bukan membongkar-bongkar konflik politik masa silam yang jelas tidak ada manfaatnya. ${ }^{1}$

\footnotetext{
${ }^{1}$ M. Amien Rais, "Kata Pengantar" dalam Ali Shari'ati, Man dan Islam ditemahkan dengan judul: Tugas Cendikiawan Muslim yang diterjemahkan oleh M. Amien Rais (Yogyakarta: Salahuddin Press, 1984), h. ix. Mengenai biografi Ali Syari'ati lebih lanjut baca Ali Rahnema (ed), Pioneers of Islmamic Revival diterjemahkan oleh Ilyas Hasan dengan judul Para Perintis Zaman Baru Islam (Cet.II; Bandung: Mizan, 1996), h. $203-239$.
} 
Senada dengan hal tersebut Abdurrahman Wahid sering mengatakan dengan stiyle dan nada kelakar bahwa Nahdlatul Ulama yang dipimpinnya adalah Syi'ah kultural. ${ }^{2}$ Maksudnya dalam tradisi NU sangat banyak dipengaruhi oleh Syi'ah. ${ }^{3}$ Abdurrahman menginginkan titik temu antara dua mazhab besar tersebut bukan menonjolkan perbedaan. Hal yang sama dikatakan oleh Nurcholish Madjid, bahkan Rektor Universitas Paramadina ini mengatakan bahwa perbedaan Sunni dan Syi'ah bukan perbedaan esensial agama melainkan ideologis. Jika ditelaah kembali lebih jauh ia berkata:

Kaum Sunnah akan dapat memetik manfaat lebih besar jika...interaksi intelektual mereka dengan kaum Syi'ah lebih terbuka dan reseptif...pemikiran filsafat di kalangan pengamat mazhab Syi'ah tidak mati. Adalah justru di Iran... di antara kaum Syi'ah, tradisi kefilsafatan tetap lestari, biarpun sesudah masa Ibnu Rusdy (Averroes). Syi'ah lebih baik daripada kaum Sunni dalam mewarisi tradisi intelektual spekulatif. ${ }^{4}$

Nurcholish juga mengutip pandangan Bertrand Russel tentang karakteristik orangorang Persia (Iran) yang memang mempunyai tradisi inteletual yang membanggakan. Russel menulis:

Orang-orang Persia, sebaliknya, sejak dari mula sangat bersemangat keagamaan dan amat spekulatif. Setelah mereka pindah agama, mereka membuat Islam menjadi sesuatu yang jauh lebih menarik, lebih bersemangat keagamaan, dan lebih filosofis, daripada yang pernah dibayangkan oleh Nabi dan para pengikutnya. ${ }^{5}$

Meskipun Ibnu Khaldum dan al-Syahrastani berpandangan bahwa letak geografis dan iklim suatu daerah ikut mempengaruhi karakteristik penduduknya. Dan bangsa Persia sama dengan bangsa Eropa menurutnya berkecenderungan fisikalistik (untuk tidak menamakan mereka "materialistik"). Sebaliknya bangsa Arab dan India memiliki kecenderungan spriritualtik. ${ }^{6}$ Tetapi Munawir menanggapi secara lebih netral bahwa keempat bangsa besar tersebut (yaitu Eropa, Arab, India dan Persia) telah memberikan sahamnya kepada sejarah peradaban dan kebudayan dunia, hal itu oleh karena bertempat tinggal di bagian-bagian bumi yang beriklim sedang. ${ }^{7}$

Pernyataan al-Syahrastani tersebut kurang dapat dipertanggung jawabkan jika melihat sejarah perkembangan Islam sampai saat ini. Sebab kebanyakan ulama dan intelektual lahir dari daratan Persia. Ulama hadis misalnya dari kutub al-sittah, empat dari Persia, apalagi ulama tasawuf dan ahli filsafat hampir semuanya dari daratan Persia.

Selanjutnya yang menjadi inti pembicaraan dan terkadang sumber perbedaan antara mazhab Syi'ah dengan Sunni adalah misalnya; konsep Imamah, wilayah al-Faqih, Syahadah (jihad). Syi'ah tidak menyebut istilah rukun Islam. Dalam pengantar kepada Syi'ah, Kasyif Githa merinci pokok-pokok ajaran Islam sebagai berikut; salat, puasa, zakat, khumus, haji,

\footnotetext{
${ }^{2}$ Imran Hamzah dan Choirul Anam, Gus Dur Diadili Kiai-Kiai (Surabaya: Jawa Pos, 1989), 27. Sebagaimana dikutip oleh Dedy Djamaluddin Malik, op. cit., h. 226.

${ }^{3}$ Mengenai tradisi-tradisi tersebut misalnya; tahlilan yang sering sekali dilakukan dalam NU, Haul bagi para Ulama, slametan bagi orang meninggal yang diklaim pengaruhi dari Hindu dan Budha padahal di dalam agama tersbut tidak ada tradisi seperti itu, bubur Syura atau 10 Muharram saat meninggal Imam Husain (peristiwa Karbala) yang banyak dilakukan di Sumatra, Jawa dan Sulawesi. Kesemuanya merupakan pengaruh dari Syiah. Jadi sangat betul ketika Abdurrahman Wahid mengatakan bahwa NU adalah Syi'ah kultural meskipun bukan Syi'ah doktrinal. Lihat misalnya Jalaluddin Rakhmat, Catatan Kang Jalal....loc. cit.

${ }^{4}$ Nurcholish Madjid, "Sekilas Tinjaun Tentang Paham Sunnah-Syi'ah" kata pengantar dalam S. Husein Jufri, Islam Syi'ah (Jakarta: Pustaka Firdaus, 1987), h. 15-16

${ }^{5}$ Bertrand Russel, A History of Westren Philosophy (New York: Shimon and Schuster, 1959), h. 421. Sebagaimana dikutip oleh Nurcholish Madjid, Islam Doktrin dan Peradaban ....op. cit., h. 548.

${ }^{6}$ Nurcholish Madjid, ibid.

${ }^{7}$ Munawir Sjadzali, Islam dan Tata Negara: Ajaran, Sejarah dan Pemikiran Edisi V (Jakarta: UI Press, 19930, 103.
} 
jihad (syahadah) dan amar ma'ruf nahi mungkar. ${ }^{8}$ Sama dengan kaum Mu'tazilah dengan ushul al-Khamsah yang juga mencantumkan konsep amar ma'ruf nahi mungkar. Berikut ini akan dikemukakan beberapa hal yang berkaitan dengan hal tersebut yang menurut Jalaluddin merupakan karakteristik dan ciri khas mazhab Syi'ah.

\section{Kajian Pustaka}

\section{Konsep Imamah}

Konsep Imamah merupakan salah satu fondasi keyakinan yang sangat fundamental dalam ajaran mazhab Syi'ah, dan pemimpinnya disebut Imamah. Sementara dalam mazhab Sunni dikenal dengan istilah khalifah dan pemerintahannya disebut khilafah.

Konsep ini berawal dari keyakinan mazhab Syi'ah bahwa sebelum Rasulullah saw. ia telah mewasiatkan kepada Ali bin Abu Thalib untuk menggantikannya sebagai pemimpin. Hal ini kemudian secara turun-temurun diyakini dan yang dikenal dengan Imam dua belas bagi Syi'ah Isna' Asyariyah.

Uraian tentang kepemimpinan Islam dalam pandangan Syi'ah bertolak dari konsep wilayah dan imamah. Wilayah adalah konsep luas yang meliputi juga imamah dan wilayah bathiniyah, sedangkan imamah adalah kepemimpinan (zia'amah), pemerintahan (hukumah) dan riasah 'ammah dalam urusan dunia dan agama, yang terdapat pada diri Nabi Muhammad saw. dan para imam sesudah Nabi. ${ }^{9}$

Jalaluddin menjelaskan bahwa setiap kelompok manusia harus mempunyai Imam, apalagi sebuah kelompok masyarakat yang terbentuk dalam lembaga negara. Nabi bukan sekedar pemimpin politik lanjut Jalaluddin, ia juga pemimpin rohani. Seperti seorang guru yang meninggalkan kelasnya, ia tidak akan menyerahkan penggantinya kepada pilihan muridmuridnya. Rasulullah saw. akan menunjuk orang yang menurutnya memenuhi kualifikasi guru rohani dan pemimpin -umat sekaligus. Ali bin Abu Thalib adalah imam Syi'ah yang pertama. Mereka kemudian menyebut beberapa ayat Alquran dan hadis yang menunjukkan wasiat Rasulullah saw. tentang Ali dan tidak mungkin di sini kita mengutip argumentasi mereka. Selanjunya hal itu dapat dibaca dalam buku; Dialog Sunni-Syi'ah, oleh Syafruddin al-Musawi cukuplah di sini dikatakan bahwa Ali pernah ditunjuk Rasulullah sebagai Khalifah, ketika Nabi saw. melancarkan perang Tabuk dan pada peristiwa Ghadir Hum. Dalam kejadian ini Nabi saw. berkata tentang Ali: "inilah saudaraku, sahabatku, khalifahku untukmu. Dengarkanlah dia dan taatilah dia."10

Imam-imam sesudah Ali bin Abu Tahlib (al-Murtadha) yaitu: Hasan bin Ali (alMujtaba), Husain bin Ali (al-Syahid), Ali Zainal Abidin (al-Sajjad), Muhammad bin Ali (alBaqir), Ja'far bin Muhammad (al-Sadiq), Musa bin Ja'far (al-Kazhim), Ali bin Musa (alRidha), Muhammad bin Ali (al-Taqi), Ali bin Muhammad (al-Naqi), Hasan bin Ali (alAsakir) Muhammad bin Hasan (al-Mahdi al-Muntazar). ${ }^{11}$ Imam kedua belas ini lahir pada 255H/869 M. dan sampai sekarang masih hidup, tetapi berada di alam gaib. Pada suatu saat nanti Imam Mahdi akan kembali lagi untuk menegakkan keadilan dan menghancurkan kezaliman di muka bumi. ${ }^{12}$

Imamiyah adalah golongan yang meyakini bahwa nabi Muhammad SAW telah menunjuk Ali bin Abi Thalib sebagai imam pengganti dengan penunjukan yang jelas dan

\footnotetext{
${ }^{8}$ Jalaluddin Rakhmat, Amar Ma'ruf nahi Mungkar dalam Muhamad Wahyuni nafis (ed.) Rekontruksi dan renungan Religius Islam (Cet. I; Jakarta: Paramadina, 1996), h. 186, catatan kaki nomor 8.

${ }^{9}$ Jalaluddin Rakhmat, Islam Alternatif....op. cit., h. 251.

${ }^{10}$ Ibid. h. 244.

${ }^{11}$ Muthadha Muthahhari, Master and Mastership...op. cit., h. 25.

${ }^{12}$ Ibid.
} 
tegas. Oleh karena itu, mereka tidak mengakui keabsahan kepemimpinan Abu Bakar, Umar, maupun Utsman. Bagi mereka persoalan imamah adalah salah suatu persoalan pokok dalam agama atau ushuludin. Sekte imamah pecah menjadi beberapa golongan. Golongan yang besar adalah golongan Isna' Asyariyah atau Syi'ah dua belas. Golongan terbesar kedua adalah golongan Isma'iliyah. Golongan Isma'iliyah berkuasa di Mesir dan Baghadad. Disebut juga Tujuh Imam. Dinamakan demikian sebab mereka percaya bahwa imam hanya tujuh orang dari 'Ali bin Abi Thalib, dan mereka percaya bahwa imam ketujuh ialah Isma'il.

Dalam konsep Syi'ah Imamiyah, imam-imam melanjutkan kepemimpinan Nabi (qiyadah nabawiyah). Imam adalah pilihan Tuhan, yang paling berilmu, berakhlak tinggi, dan terpelihara dari dosa (ma'shum). Sekarang ini di dunia Islam, tidak terdapat Imam karena Imam keduabelas dalam keadaan gaib, tetapi garis imamah dilanjutkan sementara oleh para ulama. Konsep imamah mengandung makna bahwa kepemimpinan dalam Islam meliputi aspek ruhaniah dan duniawiyah sekaligus. Orang Islam hanya boleh diatur oleh pemimpin yang melanjutkan garis imamah. Setelah wakil Imam terakhir, yaitu Ali bin Muhammad alSumri meninggal, tidak ada lagi kekuasaan yang dianggap sah, kecuali jika pemegang kekuasaan itu memenuhi syarat-syarat sebagai penerus garis imamah. Konsep ini secara terinci dijabarkan dalam konsep wilayah al-faqih. ${ }^{13}$

\section{Pembahasan}

\section{Wilayah al-Faqih}

Menurut Murthadha Mutahhari, kata wala, walayah, wilayah wali, maula dan derivasi lainnya, banyak sekali dalam Alquran. Sedangkan kata kerja disebut 124 kali, dan sebagai kata benda disebut 112 kali. Ini menunjukkan betapa pentingnya Alquran memandang penting masalah wilayah. Dalam Alquran menurut Mutahhari, dibedakan antara dua jenis wala: wala negatif dan wala positif. Umat Islam diperintahkan untuk melaksanakan wala positif, dan menghindari wala negatif. Wala positif mempunyai dua bentuk, umum dan khusus. Yang khusus dibagi lagi menjadi beberapa kategori: wala sebagai ahl al-bait, wala sebagai imamah, wala sebagai kepemimpinan, dan wala sebagai kemampuan mengendalikan atau mendominasi hal-hal yang dialami. ${ }^{14}$

Wala negatif mengacu kepada hubungan Muslim dengan orang kafir. Muslim adalah anggota umat Islam, suatu kesatuan politik dan sosial. Non-Muslim adalah anggota masyarakat lain. Seorang Muslim tidak boleh menjalin persahabatan, menunjukkan kesetiaan, atau memberikan kepemimpinan kepada orang-orang kafir. Hal ini tidak berarti bahwa musuh tidak boleh berbuat baik kepada mereka. ${ }^{15}$ Dalam hal ini Mutahhari berkata;

Posisi ini membuatnya esensial, sehingga kaum Muslimin harus hati-hati dan bijaksana terhadap kaum bukan Muslim. Mereka harus senantiasa ingat bahwa mereka berasal dari suatu masyarakat tauhid dan sepenuhnya berbeda dengan masyarakat bukan Muslim. Namun, hal itu tidaklah berarti bahwa kaum Muslim tidak boleh mengadakan hubungan sosial, ekonomi, atau politik, dengan mereka. Yang perlu dicamkan dalam

\footnotetext{
${ }^{13}$ Ibid., h. 245.

${ }^{14}$ Ibid., h. 251. Konsep wilayah al-faqih menurut sejarah telah pernah dijalankan dapat diperiodisasikan dalam empat tahap yaitu; 1) Periode perta; era Buwaihi (945-1055) 2) Periode kedua; era pasca-Seljuk dan ilkhan (abad 12-14) 3) Periode ketiga; era berdirinya negara Syi'ah dibwaha dinasti Safawi di Persia (1501-1786) dan 4) Periode keempat; era dinati Qajar dan Fas (akhir abad ke - 18 hingga awal abad ke- 20). Lihat penjelasannya dalam Tim Penyusun, Ensiklopedi Hukum Islam Jilid VI (Jakarta: Ichtiar Baru Van Hoeve, 1997), h. 1936-1937. ${ }^{15}$ Ibid., h. 252.
} 
benak ialah bahwa semua hubungan semacam itu harus selaras dengan kepentinganmenyeluruh masyarakat Muslim. ${ }^{16}$

Wala positif umum adalah wala yang menunjukkan hubungan antara sesama Muslim. Umat Islam haruslah menjadi suatu satuan yang terkoordinasi secara militer dan homogen secara sosial yang diikat oleh imam. Menurut Alquran, hubungan sesama Muslim diungkapkan dengan saling membantu, amar ma'ruf nahi mungkar, memelihara salat dan zakat, serta menaati Allah dan Rasul-Nya. ${ }^{17}$

Wala-positif khusus yaitu kecintaan kepada keluarga Rasulullah saw. Alquran meerintahkan untuk mencintai mereka: Katakanlah: Aku tidak meminta upah kepadamu atas seruanku, kecuali kasih sayang terhadap keluargaku (QS.al-Nur [42]: 23). Menurut Ibnu Abbas, al-qurba dalam ayat tersebut adalah keluarga Muhammad saw. Kasih sayang kepada keluarga Rasulullah saw. dinyatakan dengan kecintaan kepada ahl al-bait, dan bergabung bersama kelompok mereka. Kecintaan ini sebenarnya bukan monopoli kaum Syi'ah. Imam Syafi'i berkata dalam syairnya;

Mereka berkata: Aku sudah menjadi Syi'ah

Aku berkata: Syi'ah bukan agamaku dan keyakinanku

Tapi Aku beriman tanpa ragu

Kepada imam dan pemberi petunjuk terbaik

Jika mencintai Sang wali itu Syi'ah

Akulah hamba yang paling Syi'ah.

Jika Syi'ah mencintai keluarga Nabi

Hai keluarga Rasulullah

Saksikanlah jin dan manusia, aku ini Syi'ah.

Kecintaan kepadamu diwajibkan Allah

Dalam Alquran yang diturunkan

Cukuplah kemuliaan kamu

Tanpa salawat kepada kamu

Salat tidak berarti apa-apa. ${ }^{18}$

Pada kesempatan lain Imam Syafi' i juga bersya'ir;

Kalau di majlis mereka sebut Ali

Kedua putranya dan Fatimah yang suci

Segera ia menyebut selain mereka

Seraya yakin, ia di jalan yang benar

Jika mereka menyebut Ali dan anak-anaknya

Ia sibuk membawakan hadis-hadis yang tinggi

Karena semuanya hadis-hadis Syi'ah (rafidhi)

Aku berlepas diri kepada Sang pemelihara

Dari manusia yang menyebut Syi'ah

Pada kecintaan terhadap keluarga Fathimah

Semoga salawat Tuhan disampaikan kepada

keluarga Rasul

Dan laknat bagi kaum jahiliyah. ${ }^{19}$

\footnotetext{
${ }^{16}$ Murtadha Mutahhari, Master and Mastership (Teheran: Beth'ah Foundation, 1982), h. 16.

${ }^{17} \mathrm{Ibid}$.

${ }^{18}$ Syair-syair Imam Syafi'i tersebut dimuat dalam Jamal al-Zarandi, Fakruddin al-Razi dalam tafsirnya Mafatih al-Ghaib dan Ibnu Hajar al-Asqallani (al-Shawaiq al-Muhriqah) sebagaimana dikutip oleh Jalaluddin Rakhmat, Catatan Kang Jalal...op. cit., h. 431.

${ }^{19}$ Ibid., 430.
} 
Imam Syafi'i tidak diragukan kesunniannya pendiri, mazhab fikih Syafi'i, tetapi baginya bukan berarti kesunniannya mengungkung dirinya untuk mewujudkan rasa cintanya kepada ahl al-bait. Hal ini juga berarti bahwa perasaan cinta kepada ahl al-bait tidak berarti lantas mengubah mazhab dari Sunni menjadi Syi'ah.

Selanjutnya, wala imamiyah berarti mengakui kepemimpinan ahl al-bait dalam urusan agama; bahwa ucapan dan tindakan ahl al-bait bersifat otoratif. Wala positif khusus yang lain ialah menerima ahl al-bait dan kepemimpinan yang digariskannya, sebagai pemilik sah kepemimpinan politik dan sosial bagi umat Islam. Hal ini berarti menerima mereka sebagai ulil amri. Orang Syi'ah percaya bahwa Rasulullah saw. mewasiatkan kepemimpinan umat kepada Ali bin Abu Thalib kw. dan sebelas imam sesudahnya. Dengan demikian, para imam memegang empat posisi; imam adalah pemimpin agama yang bersifat otoratif; imam adalah qadhi yang keputusannya bersifat mengikat dan sah; imam memegang kepemimpinan politik dan sosial; imam juga pemilik wilayah bathiniyah. Posisi keempat ini adalah wala positif yang menyangkut kehidupan batiniah. Menurut kaum Syi'ah, manusia memiliki kemampuan untuk menyempurnakan dirinya. Bila orang sudah mengikuti jalan Islam dan jalan ibadah, serta makin lama makin dekat dengan Allah, maka ia akan menjadi manusia sempurna yang mampu mempengaruhi dunia secara adialami. Menurut Syi'ah, dunia tidak pernah tidak mempunyai manusia seperti itu. Para imam dari ahl al-bait adalah juga pemilik walayat dalam pengertian keempat ini. Imam adalah "pemimpin kafilah ruhani, wali (master) hati nurani umat, saksi bagi amal-amal mereka, dan pewenang kompoten di masanya." ${ }^{20} \mathrm{Di}$ sini tampak bahwa kepemimpinan dalam Syi'ah meliputi aspek lahiriyah dan batiniyah sekaligus.

Sementara itu, prinsip-prinsip wilayah al-faqih didasarkan pada empat dasar falsafi (philosophische grondslag) yaitu; 1) Allah adalah hakim seluruh alam semesta dan segala isinya. 2) Kepemimpinan manusia (qiyadah basyariyah) yang mewujudkan hakimiyah Allah di bumi ialah nubuwah. 3) Garis imamah melanjutkan garis nubuwah dalam memimpin umat. 4) Para fakih adalah khalifah para imam dan kepemimpinan umat dibebankan kepada mereka. ${ }^{21}$

Kepemimpinan Islam adalah kepemimpinan yang berdasarkan hukum Allah. Karena itu, pemimpin haruslah orang yang paling tahu tentang hukum ilahi. Setelah para imam tiada, maka kepemimpinan harus dipegang oleh para fakih yang memenhi syarat-syarat tertentu. Bila tak seorang fakih pun memenuhi syarat, maka harus dibentuk "majelis fukaha". Prinsip ini dengan jelas tampak pada pasal 5, Konstitusi Republik Islam Iran;

Selama ghaib-nya Imam zaman (semoga Allah segera menghadirkan kembali beliau), pemerintahan dan kepemimpinan bangsa berpindah kepada fakih yang adil dan takwa, yang mengenal keadaan-keadaan masanya; berani pandai, dan memiliki kemampuan administratif; diakui dan diterima sebagai pemimpin oleh mayoritas rakyat. Bila tidak ada fakih yang diakui oleh mayoritas rakyat, maka pemimpin, atau dewan kepemimpinan, yang terdiri atas para fakih yang memiliki persyaratan tersebut di atas, akan mengemban tanggungjawab itu sesuai dengan pasal $107 .^{22}$

Menunggu kedatangan Imam yang ghaib disebut sebagai intizar. Ali Syariati seorang tokoh revolusi Islam Iran memberikan penafsiran yang menarik dan kreatif tentang intizhar tersebut. Menurut Syariati intizhar berarti secara aktif menunggu kedatangan kebenaran yang harus diperjuangkan. Intizhar juga berarti bahwa orang tidak boleh puas dengan keadaan yang ada, karena kepuasan akan membeku menjadi stagnasi, kejumudan dan dekadensi. ${ }^{23}$

\footnotetext{
${ }^{20}$ Murtadha Mutahhari, op. cit., h. 41.

${ }^{21}$ Jalaluddin Rakhmat, Islam Alternatif...op. cit., h. 254-254.

${ }^{22}$ Ibid., h. 255.

${ }^{23}$ M.Amien Rais, Cakrawala Islam: Antara Cita dan Fakta (Cet.X; Bandung: Mizan, 1999), h. 204.
} 
Sedangkan fakih adalah Muslim yang sudah mencapai tingkat tertentu dalam ilmu dan kesalehan. Seorang fakih disyaratkan harus mengetahui semua peraturan Allah; mampu membedakan Sunnah yang sahih dan yang palsu, yang mutlak dan yang terbatas, yang umum dan khusus. Ia juga harus mampu menggunakan akalnya untuk membedakan hadis dari situasi lain, situasi taqiyah atau situasi lain, serta memahami kriteria yang telah ditetapkan. ${ }^{24}$

Secara terperinci, seorang fakih antara lain harus mencukupi syarat-syarat berikut;

1) Faqahah: mencapai derajat mujtahid mutlaq yang sanggup melakukan isntinbat hukum dari sumber-sumbernya.

2) 'Adalah: memperhatikan ketinggian kepribadian, dan bersih dari watak buruk. Hal ini ditunjukkan dengan sifat istiqamah, ash-shalah, dan tadayyun.

3) Kifaah: Memiliki kemampuan untuk memimpin umat; mengetahui ilmu yang berkaitan dengan pengaturan masyarakat, cerdas, matang secara kejiwaan dan ruhani. $^{25}$

Penjelasan tersebut di atas terkait dengan personal persyaratan seorang fakih, kemudian fakih sekaligus ulama mempunyai tugas-tugas Ain Najaf menyebut enam tugas yaitu; a) tugas intelektual b) tugas bimbingan keagamaan c) tugas komunikasi dengan umat (al-ittishal bi al-ummah) d) tugas menegakkan syi'ar Islam e) tugas mempertahankan hakhak umat f) tugas berjuang melawan musuh-musuh Islam dan kaum Muslimin. Tugas-tugas teresbut dapat dijelaskan a) Tugas pertama; ia harus mengembangkan berbagai pemikiran sebagai rujukan umat. Ia dapat mengembangkan pemikiran ini dengan mendirikan majlismajlis ilmu, pesantren, atau hauzah; menyusun kitab-kitab yang bermanfaat bagi manusia yang meliputi Alquran, hadis, aqaid, fiqh, ushul fikih, ilmu-ilmu aqliyah, matematika, tarikh, ilmu bahasa, kedokteran, biologi, kimia dan fisika; dan membuka perpustakaan-perpustakaan ilmiah. b) Tugas kedua: ia harus menjadi rujukan (marja) dalam menjelaskan halal-haram. Ia mengeluarkan fatwa tentang berbagai hal yang berkenaan dengan hukum-hukum Islam. c) Tugas ketiga: ia harus dekat dengan umat yang dibimbingnya. Ia tidak boleh terpisah dan membentuk kelas elit. Akses pada umat diperolehnya melalui hubungan langsung, mengirim wakil ke setiap daerah secara permanen, atau menyampaikan khotbah. d) Tugas keempat: ia harus memelihara, melestarikan dan menegakkan berbagai manifestasi ajaran Islam. Ini dapat dilakukannya dengan membangun masjid, meramaikannya, dan menghidupkan ruh Islam di dalamnya; dengan menyemarakkan upacara-upacara keagamaan dan merevitalisasikan maknanya dalam kehidupan yang aktual; dan dengan menghidupkan sunnah Rasulullah saw. sambil menghilangkan bid'ah-bid'ah jahiliyah dalam pemikiran dan kebiasaan umat. e) Tugas kelima: ia harus tampil membela kepentingan umat, bila hak-hak mereka dirampas. Ia harus berjuang "meringankan" penderitaan mereka dan melepaskan belenggu-belenggu yang memasung kebebasan mereka. f) Tugas keenam: ulama adalah mujahidin yang siap menghadapi lawan-lawan Islam bukan saja dengan pena dan lidah, tetapi juga dengan tangan dan dada. Mereka selalu mencari syahadah sebagai kesaksian atas komitmennya yang total terhadap Islam. ${ }^{26}$

Kedudukan, sifat, dan kewajiban ulama seperti dalam sistem falsafi wilayah al-faqih, jika dipahami betapa beratnya tantangan yang dihadapi para fukaha Syi'ah. Mereka harus menjadi fakih, intelektual, pemimpin politik, pelindung umat, dan bahkan pemimpin militer. Terkait dengan hal tersebut Mutahhari menulis;

1) Seorang wali mengingatkan manusia akan musuh-musuhnya dan menanamkan semangat dan melawan penindas.

2) Seorang wali menanamkan cinta kepada keindahan Ilahiyah.

\footnotetext{
${ }^{24}$ Ibid., h. 256 .

${ }^{25}$ Ibid.

${ }^{26}$ Lihat ibid., h. 256-257.
} 
3) Seorang wali menanamkan cinta kepada manusia kebencian akan maksiat dan dosa.

4) Seorang wali menunjukkan asal mula perintah, petunjuk dan hukum yang harus dipatuhi.

5) Seorang wali melatih manusia untuk melindungi dan memelihara benteng ideologi di atas dengan segala risikonya.

6) Seorang wali mengajar manusia untuk memegang teguh dan menjaga syariat setelah memerangi dan menundukkan nafsu-nafsunya yang rendah.

7) Seorang wali menanamkan pada diri manusia hasrat untuk taqqarrub kepada Allah, berkhidmat kepada manusia, berbuat baik dan penyayang pada semua makhluk Allah. $^{27}$

\section{Kesimpulan}

Jadi dengan demikian, konsep Syi'ah, bahwa kepemimpinan manusia bersumber pada kepemimpinan Ilahiyah. Allah memilih manusia sebagai khalifah di bumi. Untuk keselamatan manusia, dipilih-Nya manusia yang sudah mempunyai kesempurnaan dalam sifat dan perkembangan kepribadiannya. Manusia-manusia ini adalah para Nabi yang menjadi imam dalam urusan agama, dan pemimpin dalam urusan kemasyarakatan. Para Nabi dilanjutkan oleh para aushiya (penerima wasiat). Dari para aushiya dilanjutkan oleh para fakih. Kepemimpinan manusia dengan demikian, merupakan keneradaan kepemimpinan Allah atas manusia. ${ }^{28}$

Sampai di sini, kaum Syi'ah meyakini kesatuan kepemimpinan yaitu kepemimpinan duniawi (sosial pemerintahan) dan kepemimpian rohani (spiritual keagamaan). Tetapi yang menarik adalah seleksi untuk menjadi seorang fakih yang sangat sulit dan ekstra ketat. Oleh karena itu, tidak sukar menemukan di kalangan Syi'ah seorang pemimpin elit birokrasi yang fakih dan mendalam pengetahuan agamanya pada diri seseorang sekaligus.

\section{Daftar Pustaka}

M. Amien Rais, "Kata Pengantar" dalam Ali Shari'ati, Man dan Islam ditemahkan dengan judul: Tugas Cendikiawan Muslim yang diterjemahkan oleh M. Amien Rais (Yogyakarta: Salahuddin Press, 1984), h. ix.

Ali Rahnema (ed), Pioneers of Islmamic Revival diterjemahkan oleh Ilyas Hasan dengan judul Para Perintis Zaman Baru Islam (Cet.II; Bandung: Mizan, 1996), h. 203-239.

Imran Hamzah dan Choirul Anam, Gus Dur Diadili Kiai-Kiai (Surabaya: Jawa Pos, 1989), 27.

Nurcholish Madjid, "Sekilas Tinjaun Tentang Paham Sunnah-Syi'ah" kata pengantar dalam S. Husein Jufri, Islam Syi'ah (Jakarta: Pustaka Firdaus, 1987), h. 15-16

Bertrand Russel, A History of Westren Philosophy (New York: Shimon and Schuster, 1959), h. 421. Sebagaimana dikutip oleh Nurcholish Madjid, Islam Doktrin dan Peradaban....op. cit., h. 548.

Munawir Sjadzali, Islam dan Tata Negara: Ajaran, Sejarah dan Pemikiran Edisi V (Jakarta: UI Press, 19930, 103.

Jalaluddin Rakhmat, Amar Ma'ruf nahi Mungkar dalam Muhamad Wahyuni nafis (ed.) Rekontruksi dan renungan Religius Islam (Cet. I; Jakarta: Paramadina, 1996), h. 186, catatan kaki nomor 8.

${ }^{27}$ Ibid., h. 257-258.

${ }^{28}$ Ibid. 
Murtadha Mutahhari, Master and Mastership (Teheran: Beth'ah Foundation, 1982), h. 16.

Syair-syair Imam Syafi'i tersebut dimuat dalam Jamal al-Zarandi, Fakruddin al-Razi dalam tafsirnya Mafatih al-Ghaib dan Ibnu Hajar al-Asqallani (al-Shawaiq al-Muhriqah) sebagaimana dikutip oleh Jalaluddin Rakhmat, Catatan Kang Jalal...op. cit., h. 431.

M.Amien Rais, Cakrawala Islam: Antara Cita dan Fakta (Cet.X; Bandung: Mizan, 1999), h. 204. 